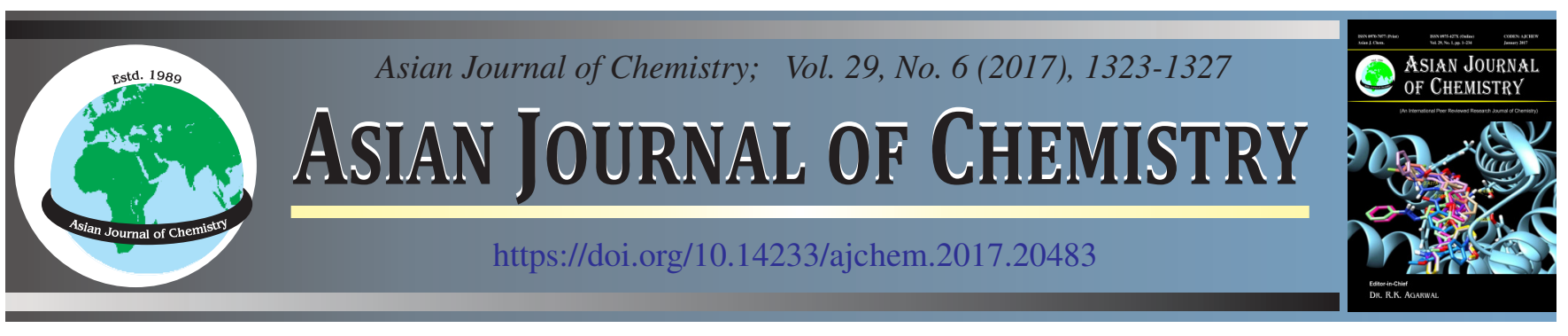

\title{
Green Synthesis of Zinc Oxide Nanoparticles Using Fresh Stem of Cissus quadrangularis Extract and its Various in vitro Studies
}

\author{
V.N. Kalpana, Rupali Rashmita Patra and V. Devi Rajeswari*
}

Department of Biomedical sciences, School of Biosciences and Technology, VIT University, Vellore-632 014, India

*Corresponding author: E-mail: vdevirajeswari@vit.ac.in

\begin{abstract}
The green synthesis of metal and metal-oxide nanoparticles is a growing research area due to the potential applications in the growth of novel technologies. The present work reports low-cost, green synthesis of zinc oxide nanoparticles using Cissus quadrangularis stems extract. The biosynthesized nanoparticles were characterized by UV, FTIR, XRD and SEM. The synthesized ZnO nanoparticles were pure, predominantly spherical in shape with the size ranging from 23 to $64 \mathrm{~nm}$. In the present study the biosynthesized ZnO nanoparticles have been used for various in vitro activities such as antihelmintic, antibacterial, antiarthritic and antioxidant activities. Zinc oxide nanoparticles demonstrated antioxidant activity by scavenging $36 \%$ hydrogen peroxide at $100 \mu \mathrm{g} / \mathrm{mL}$ and revealed excellent antihelmintic effect by show casing the death of the worm at all the concentrations at different times. The antibacterial study was done by agar-well diffusion method and the maximum inhibition zones around the $\mathrm{ZnO}$ nanoparticles were observed in E. coli followed by $S$. aureus, Listeria sp, Salmonella sp and Klebsiella sp. The percentage stabilization of aqueous extract was found to be $93 \%$ inhibition on bovine serum albumin method and $91 \%$ inhibition on egg albumin denaturation method which confirms the antiarthritic activity. Therefore, the study reveals an eco-friendly, efficient and simple method for the green synthesis of multifunctional $\mathrm{ZnO}$ nanoparticles using green synthetic approach.
\end{abstract}

Keywords: Earthworms, Egg albumin denaturation method, Hydrogen per oxide, SEM.

\section{INTRODUCTION}

The development of the processes for the synthesis of nanoparticles is evolving into a vital branch of engineering [1]. Green synthesis of nanoparticles is an eco-friendly approach which could pave the method for researchers across the world to explore the potential of various herbs so as to synthesize nanoparticles [2]. In recent years, a fast development of nanotechnology has opened up a world of recent potentialities for fabricating nanomaterials of desired particle size, shapes suitable for uses in biomedicine, trade and agriculture field [3]. Zinc oxide may be a distinctive material that exhibits conductive, electricity and pyro-electric properties and has versatile applications in, transparent electronics, ultraviolet (UV) light emitters, electricity devices, chemical sensors, spin electronics, personal care products, coating and paints [4]. The $\mathrm{ZnO}$ nanoparticles have been prepared by both physical and chemical methods [5]. Recently, biological methods for the synthesis of $\mathrm{ZnO}$ nanoparticles using microorganisms, enzymes and plant extracts have been suggested as possible eco-friendly alternatives to chemical and physical methods [6]. Plants and their extracts provide a biological synthesis route of several metallic and metal oxide nanoparticles which are more eco-friendly and allows a controlled synthesis with well-defined size and shape [4]. Among the metal oxide nanoparticles, $\mathrm{ZnO}$ nanoparticles are considered more and used because of their chemical stability and strong adsorption ability [7]. Many researchers reported the biosynthesis of $\mathrm{ZnO}$ nanoparticles using plant extracts such as Camellia sinesis [8], Olea europea [6], Trifolium pretense [9], Solanum nigrum [10], Couroupita guianensis [11], Limonia acidissima L [12].

Cissus quadrangularis (Family: Vitaceae) also known as Vitis quadrangularis is a vining plant native to India and Africa that has been used medicinally for centuries. It is a common perennial climber and is distributed throughout India, particularly in tropical regions. It has employed in Ayurveda as an alternate antihelminthic, dyspeptic, digestive, tonic, analgesic in eye and ear diseases and within the treatment of irregular menses and respiratory disease. The whole plant is employed in oral rehydration; while the leaf, stem and root extracts of this plant are vital within the management of assorted ailments [13]. The plant has been prescribed in Ayurveda as an alternative to treat diseases such as digestive, tonic, analgesic in ear and eye diseases and also in the treatment of irregular 
menstruation and asthma. Some other reports on Cissus quadrangularis justifies its effectiveness in management of obesity and complications associated with metabolic disorders. The aim of the present study is to develop a green process for the production of $\mathrm{ZnO}$ nanoparticles using aqueous stem extract of Cissus quadrangularis and to test its various biological applications.

\section{EXPERIMENTAL}

Zinc nitrate was obtained from Hi-media and distilled water was used throughout the experiments.

Preparation of $\boldsymbol{C}$. quadrangularis plant extract: Fresh green young stems of Cissus quadrangularis (Commonly called as Pirandai) were collected from Sevoor (Vellore district, Tamil Nadu, India) and used for the preparation of aqueous extracts. The surface of the plants was cleaned with running tap water, followed by double distilled water to remove the impurities. $25 \mathrm{~g}$ of young stem was cut into fine pieces and boiled with $100 \mathrm{~mL}$ of sterile distilled water at $60{ }^{\circ} \mathrm{C}$ for $1 \mathrm{~h}$. Then, the extract was filtered through Whatmann No. 1 filter paper and used for further experiments.

Qualitative phytochemical screening: The aqueous extracts of $C$. quadrangularis were screened for different phytochemical constituents'viz., carbohydrates, phenol, alkaloid, tannin, flavonoid and saponin. Phytochemical screening of the extracts was carried out by the standard methods [14].

Synthesis of zinc oxide nanoparticles: For the synthesis of nanoparticles, zinc nitrate $(5 \mathrm{mM})$ was mixed with $100 \mathrm{~mL}$ of double distilled water. $75 \mathrm{~mL}$ of zinc nitrate solution was mixed with $25 \mathrm{~mL}$ of plant extract. Then, the suspension was kept under stirring for $10 \mathrm{~h}$ at room temperature.

Characterization of synthesized zinc oxide nanoparticles: The synthesized $\mathrm{ZnO}$ nanoparticles were characterized by UV-visible spectroscopy, scanning electron microscope (SEM), X-ray diffraction (XRD) and Fourier transform infrared spectroscopy (FTIR) analysis [15]. Eco-friendly synthesized $\mathrm{ZnO}$ nanoparticles were monitored by UV-visible spectrometry (Schimadzu UV-visible spectrophotometer, model UV-1800). FT-IR spectrum analyzed for functional group identification using (Jasco-6600). The XRD Patterns were recorded in an Xray diffractometer (Seifert Jso-Debyerex-2002). The morphology and size distribution were characterized using SEM [10].

Antibacterial activity: The antimicrobial activity of $\mathrm{ZnO}$ nanoparticles was evaluated against bacterial pathogens such as Escherichia coli, Staphylococcus aureus, Salmonella sp, Listeria sp and Klebsiella pneumonia by disc diffusion method [14]. Sterilized discs were soaked in aqueous plant extract and synthesized $\mathrm{ZnO}$ nanoparticles. The sterile, dried antimicrobial discs impregnated with crude plant extracts and $\mathrm{ZnO}$ nanoparticles were carefully dispensed with uniform distances placed on Muller-Hinton agar plates and incubated for 18-24 h at $37{ }^{\circ} \mathrm{C}$. The zone of inhibition was measured from the centre of the disc to the clear zone in millimeter and the results were recorded.

Antihelminthic activity: Indian adult earthworms (Pheretima posthuma) were used for the evaluation of in vitro antihelmintic activity. Earthworms were collected from moist soil (VIT University, Vellore) and washed with normal saline to remove the external matter. Prepared C. quadrangularis extract and $\mathrm{ZnO}$ nanoparticles were used for antihelmintic study. Solution of standard antihelmintic drug (Albendazole, $15 \mathrm{mg} / \mathrm{mL}$ ) was also prepared in distilled water. Normal saline is used as a control. Five groups of the approximately equal size of earthworms, consisting of three in number in each group, were released into each petri-dish. Observations were made for the time taken for paralysis and death of individual worms. Time for the death of worms was recorded when ascertaining that the worms neither moved when shaken vigorously nor when dipped in warm water at $500{ }^{\circ} \mathrm{C}$. The antihelmintic activity was evaluated by adopting the quality technique [16].

\section{Antioxidant activity}

Hydrogen peroxide scavenging activity: The ability of C. quadrangularis extracts to scavenge hydrogen peroxide was determined according to the method [17]. A solution of hydrogen peroxide $(40 \mathrm{mM})$ was prepared in phosphate buffer (pH 7.4). Extracts and $\mathrm{ZnO}$ nanoparticles $(100 \mu \mathrm{g} / \mathrm{mL})$ were added to a hydrogen peroxide solution. The absorbance of hydrogen peroxide at $230 \mathrm{~nm}$ was determined after $10 \mathrm{~min}$ against a blank solution containing the phosphate buffer without hydrogen peroxide. The percentage of hydrogen peroxide scavenging of both $C$. quadrangularis extracts and $\mathrm{ZnO}$ nanoparticles with standard compounds ( $\alpha$-tocopherol) were calculated:

$$
\text { Scavenged }\left[\mathrm{H}_{2} \mathrm{O}_{2}\right](\%)=\frac{\left(\mathrm{A}_{\mathrm{C}}-\mathrm{A}_{\mathrm{S}}\right)}{\mathrm{A}_{\mathrm{C}}} \times 100
$$

where $A_{C}$ is the absorbance of the control and $A_{S}$ is the absorbance in the presence of the sample of C. quadrangularis extracts and $\mathrm{ZnO}$ nanoparticles or standards [18].

Antiarthritic activity: The in vitro antiarthritic activity was studied using bovine serum protein denaturation method and egg albumin denaturation method.

Bovine serum protein denaturation method: Various concentrations $(25,50,75,100 \mu \mathrm{g} / \mathrm{mL}$ ) of test dugs (plant extract and $\mathrm{ZnO}$ nanoparticles) and standard drug diclofenac sodium $(100 \mu \mathrm{g} / \mathrm{mL})$ were taken respectively and $0.5 \% \mathrm{w} / \mathrm{V}$ BSA is mixed. The samples were incubated at $37^{\circ} \mathrm{C}$ for $20 \mathrm{~min}$ and the temperature was increased to $57^{\circ} \mathrm{C}$ for $3 \mathrm{~min}$. After cooling, $2.5 \mathrm{~mL}$ of phosphate buffer was added to the above solutions. The absorbance was measured using UV-visible spectrophotometer at $255 \mathrm{~nm}$. The control represents $100 \%$ protein denaturation. The results were compared with diclofenac sodium. The percentage inhibition of protein denaturation can be calculated as follows.

$$
\text { Inhibition }(\%)=\left(100-\frac{\mathrm{OD}_{\text {control }}-\mathrm{OD}_{\text {test }}}{\mathrm{OD}_{\text {control }}}\right) \times 100
$$

Egg albumin denaturation method: The reaction mixture $(5 \mathrm{~mL}$ ) consist of $0.2 \mathrm{~mL}$ of egg albumin (from fresh hen's egg), $2.8 \mathrm{~mL}$ of phosphate-buffered saline (PBS, pH 6.4) and $2 \mathrm{~mL}$ of varying concentrations $(25,50,75,100 \mu \mathrm{g} / \mathrm{mL})$ of plant extract and $\mathrm{ZnO}$ nanoparticles. A similar volume of double-distilled water served as the control. Next, the mixtures were incubated at $37 \pm 2{ }^{\circ} \mathrm{C}$ in a BOD incubator for $15 \mathrm{~min}$ and then heated at $70{ }^{\circ} \mathrm{C}$ for $5 \mathrm{~min}$. After cooling, their absorbance was measured at $660 \mathrm{~nm}$. 
Diclofenac sodium was used as the reference drug and treated similarly for the determination of absorbance. The percentage inhibition of protein denaturation wascalculated by using the following formula:

$$
\text { Inhibition }(\%)=100 \times\left(\frac{\mathrm{V}_{\mathrm{t}}}{\mathrm{V}_{\mathrm{c}}}-1\right)
$$

where, $\mathrm{V}_{\mathrm{t}}=$ absorbance of the test sample, $\mathrm{V}_{\mathrm{c}}=$ absorbance of control.

\section{RESULTS AND DISCUSSION}

Qualitative phytochemical analysis: Preliminary phytochemical screening of Cissus quadrangularis has shown the presence of alkaloids, tannins, flavonoids, saponins, steroids, triterpenoids, proteins, carbohydrates and glycosides.

UV-visible spectroscopy: The optical absorption spectra of $\mathrm{ZnO}$ dispersed in water were recorded using UV-visible spectrophotometer. UV-spectra were measured at room temperature in a quartz cuvette with the path length of $1 \mathrm{~cm}$. It is known that UV-visible spectroscopy is the most widely used technique for the structural characterization of nanoparticles. Also, the absorbance of the reaction mixture was monitored after $24 \mathrm{~h}$ of reaction. Fig. 1 shows the UV-visible absorption spectrum of $\mathrm{ZnO}$ nanoparticles sample at different times. Typical absorption at $310 \mathrm{~nm}$ was observed at room temperature. This reveals that Cissus quadrangularis exhibits the stable synthesis of $\mathrm{ZnO}$ nanoparticles.

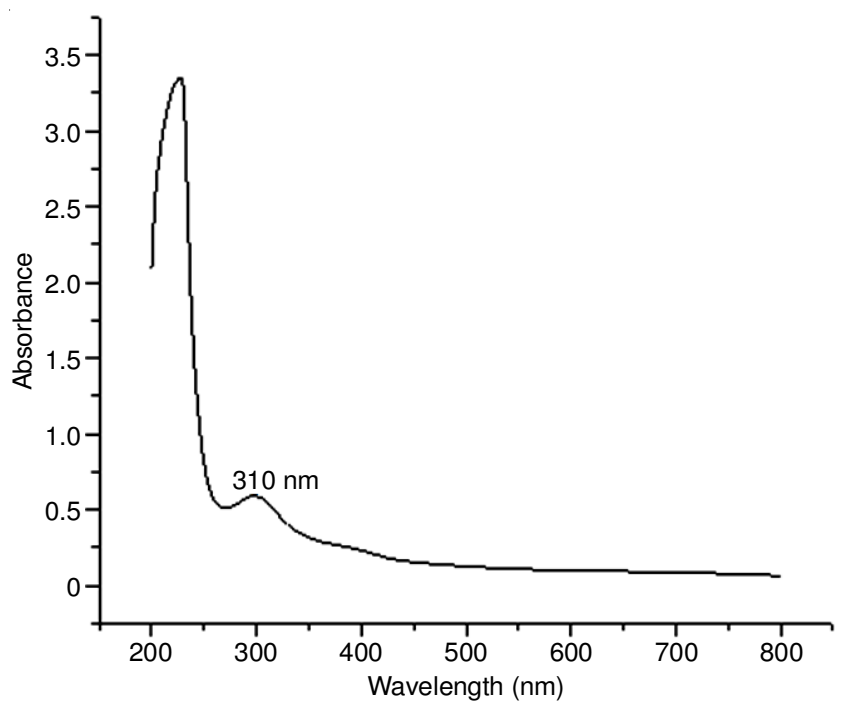

Fig. 1. UV-visible spectrum of $\mathrm{ZnO}$ nanoparticles

FTIR: The results were further reinforced by FT-IR analysis, which showed the shifts and difference in areas of the peaks. Fig. 2 shows the IR spectrum of $\mathrm{ZnO}$ nanoparticles. The FTIR bands of biosynthesized $\mathrm{ZnO}$ nanoparticles using Cissus quadrangularis were indicated at 3334.92 (Bond: $\mathrm{O}-\mathrm{H}$ stretch), 2920.23 (Bond: C-H Stretch), 2850.79 (Bond: O-H stretch), 1726.29 (Bond: $\mathrm{C}=\mathrm{O}$ stretch) and 1631.78 (Bond: $\mathrm{C}=\mathrm{C}$ stretch). This present study revealed that the FTIR band proved the appearance of alcohol, alkyl, carboxylic acids, amides, ketones, aldehydes, esters, alkene, aromatic ring.

XRD: Fig. 3 shows XRD patterns of $\mathrm{ZnO}$ nanoparticles synthesized. The characteristic patterns are corresponding to

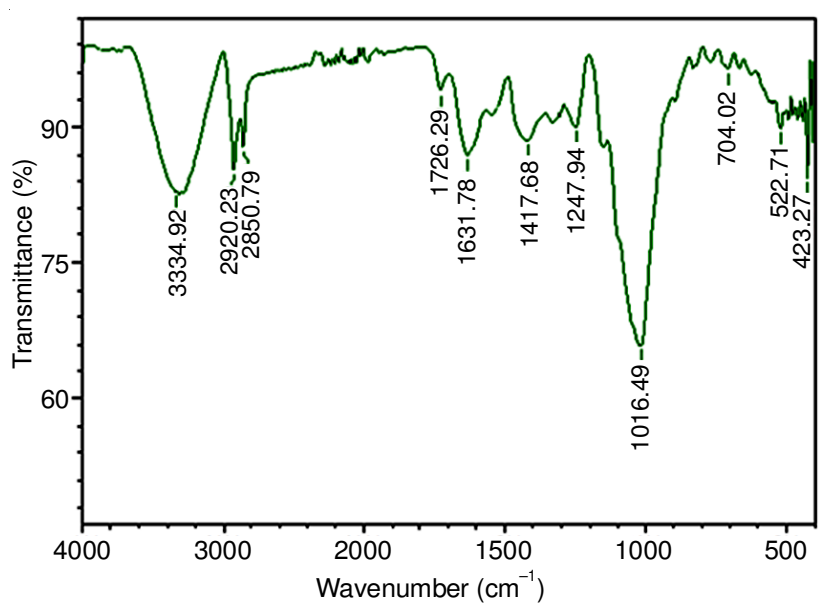

Fig. 2. FTIR spectrum of $\mathrm{ZnO}$ nanoparticles

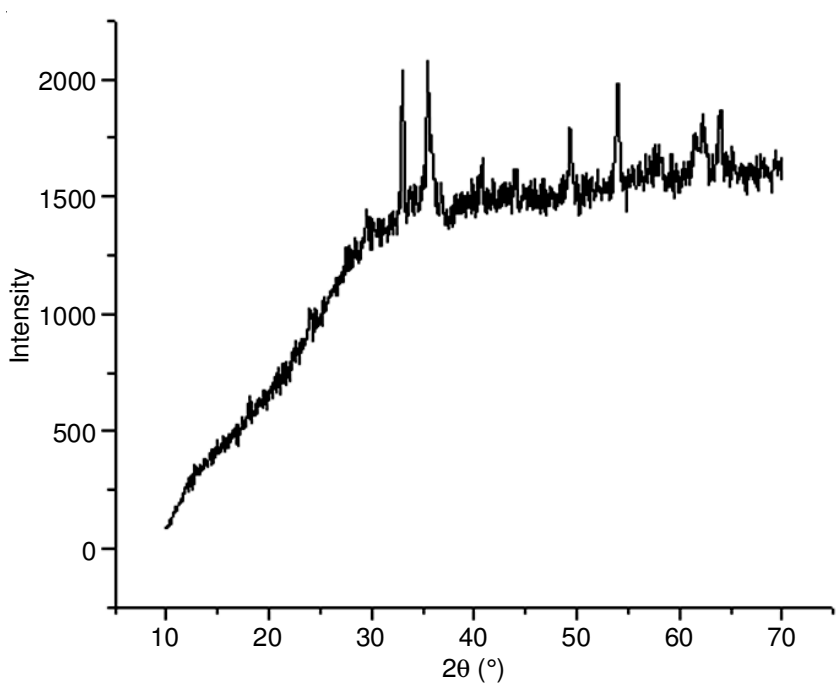

Fig. 3. XRD spectrum of $\mathrm{ZnO}$ nanoparticles

the diffraction patterns of hexagonal wurtzite phase of $\mathrm{ZnO}$. No other peaks appeared in the patterns. The cell constants were observed to be $\mathrm{a}=3.25 \AA$ and $\mathrm{c}=5.21 \AA$ and all the peaks were well matched with the JCPDS card No. 89-7123. The XRD peaks were identified as (100), (002), (101), (110), (112) and (202) reflections, respectively. Apparently, the introduction of different plant extracts favour relatively smallsize $\mathrm{ZnO}$ nanoparticles, since the average size of $\mathrm{ZnO}(82 \mathrm{~nm})$ is larger compared to $\mathrm{ZnO}$ samples prepared with plant extracts in the size range 23-64 $\mathrm{nm}$. This suggested that the use of plant extract restricts the growth of crystallites.

SEM: The pure $\mathrm{ZnO}$ nanoparticles formed was agglomerated with a hexagonal and cubical structures and a particle size ranging from 76 to $97 \mathrm{~nm}$ with some deviations. This agglomeration is due to polarity and electrostatic attraction of $\mathrm{ZnO}$ nanoparticles.

Antibacterial activity: The synthesized $\mathrm{ZnO}$ nanoparticles and aqueous plant extract $C$. quadrangularis had tested for its ability to inhibit the growth of Escherichia coli, Staphylococcus aureus, Salmonella sp, Listeria sp, Klebsiella sp. Among the tested bacterial isolates, the nanoparticles showed maximum inhibition against E.coli followed by S. aureus, Listeria sp, Salmonella sp, Klebsiella sp. The aqueous plant extract $C$. quadrangularis showed maximum inhibition against $E$. coli 
followed by Listeria $s p$, S.aureus, Salmonella sp, Klebsiella sp. The zones are presented in Table-1. This result suggests that the $\mathrm{ZnO}$ nanoparticles and the aqueous plant extract $C$. quadrangularis have the potential against several bacteria species. Similar quite results stating that the $\mathrm{ZnO}$ nanoparticles produces a maximum zone of inhibition against Pseudomonas aeruginosa followed by Proteus mirabilis, Bacillus cereus, Escherichia coli and Staphylococcus aureus. The author recommended that the green synthesized $\mathrm{ZnO}$ nanoparticles are often used as an alternate to existing antimicrobial agents [8].

\begin{tabular}{ccc}
\multicolumn{3}{c}{ TABLE-1 } \\
& ANTIBACTERIAL ACTIVITY \\
\hline Microorganism & ZnO nanoparticles (mm) & Plant extract (mm) \\
\hline E. coli & $21 \pm 0.23$ & $11 \pm 0.62$ \\
S. aureus & $15 \pm 0.77$ & $8 \pm 0.36$ \\
Listeria & $10 \pm 0.58$ & $9 \pm 0.45$ \\
Salmonella & $8 \pm 0.46$ & $7 \pm 0.18$ \\
Klebsiella & $6 \pm 0.13$ & $3 \pm 0.91$ \\
\hline
\end{tabular}

Antihelmintic activity analysis: Zinc oxide nanoparticles using $C$. quadrangularis showed better antihelmintic activity when compared with the aqueous extract of $C$. quadrangularis. Nanoparticles show less time to cause paralysis and death of worms followed by the aqueous extract. The data obtained on the antihelminthic activities of normal saline, standard drug, different concentrations of the aqueous extract and $\mathrm{ZnO}$ nanoparticles overall revealed the concentration dependent nature of the extract and $\mathrm{ZnO}$ nanoparticles in bringing out this bioactivity. It was found that the colloidal suspension of $\mathrm{ZnO}$ nanoparticles prepared in C. quadrangularis extract showed more antihelminthic activity than the aqueous extract of $C$. quadrangularis. From this study it may be concluded that the phytochemical components along with the $\mathrm{ZnO}$ nanoparticles have more antihelmintic activity (Table-2). Results of [19] demonstrated the bioavailabilty of $\mathrm{ZnO}$ nanoparticles throughout the cross sections of earthworms. This reveals that intact $\mathrm{ZnO}$ nanoparticles can be taken by the earthworm from soil and proved to be a good potential of bioremediation into non-toxic forms (Fig. 4).

\section{Antioxidant activity}

Hydrogen peroxide scavenging activity: The scavenging ability of aqueous extracts and $\mathrm{ZnO}$ nanoparticles of $C$. quad-

\begin{tabular}{ccccc}
\multicolumn{5}{c}{ TABLE-2 } \\
ANTIHELMINTHIC ACTIVITY & \\
\hline \multirow{2}{*}{ Group } & Treatment & $\begin{array}{c}\text { Concentration } \\
(\mathrm{mg} / \mathrm{mL})\end{array}$ & $\begin{array}{c}\text { Time } \\
\text { taken for } \\
\text { paralysis }\end{array}$ & $\begin{array}{c}\text { Time } \\
\text { taken for } \\
\text { death }\end{array}$ \\
\hline 1 & Normal control & - & - & - \\
2 & Positive control & 100 & 15 & 20 \\
3 & Negative control & - & - & - \\
\hline & & 5 & 64 & 70 \\
4 & Plant extract & 25 & 59 & 63 \\
& & 50 & 43 & 54 \\
& & 100 & 34 & 42 \\
\hline & & 5 & 42 & 49 \\
5 & Zinc oxide & 25 & 39 & 42 \\
& nanoparticles & 50 & 28 & 36 \\
& & 100 & 15 & 22 \\
\hline
\end{tabular}

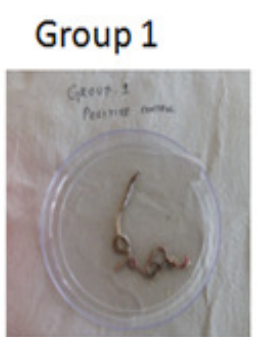

Group 2

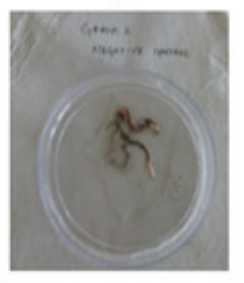

Group 3

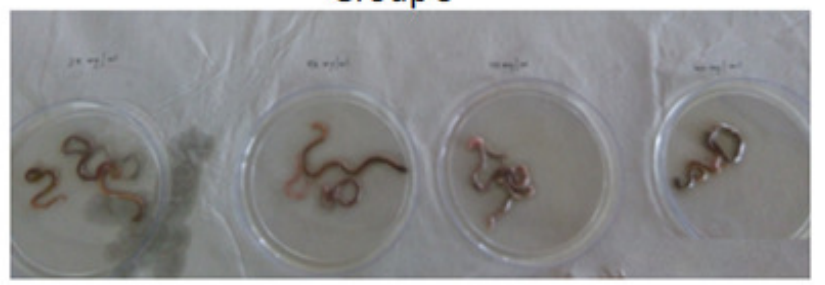

Group 4

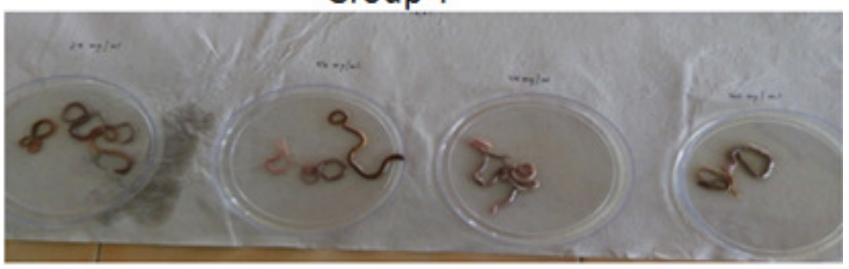

Group 1: Positive Control Group 2: Negative control

Group 3: Plant extract Group 4: ZnO NPs

Fig. 4. Antihelminthic activity of zinc oxide nanoparticles

rangularis on hydrogen peroxide is shown Fig. 5, Table-3 and compared with $\alpha$-tocopherol as standards. $100 \mu \mathrm{g}$ of extracts of $C$. quadrangularis exhibited $22 \%$ scavenging activity and Synthesized $\mathrm{ZnO}$ nanoparticles exhibits $36 \%$ Scavenging activity on hydrogen peroxide. On the other hand, using the same amounts, $\alpha$-tocopherol exhibited $44.58 \%$ hydrogen peroxide scavenging activity. Hydrogen peroxide itself is not very reactive, but it can sometimes be toxic to the cell because of it may give rise to hydroxyl radical in the cells. Thus, the removing of $\mathrm{H}_{2} \mathrm{O}_{2}$ is very important for antioxidant defense in cell or food systems.

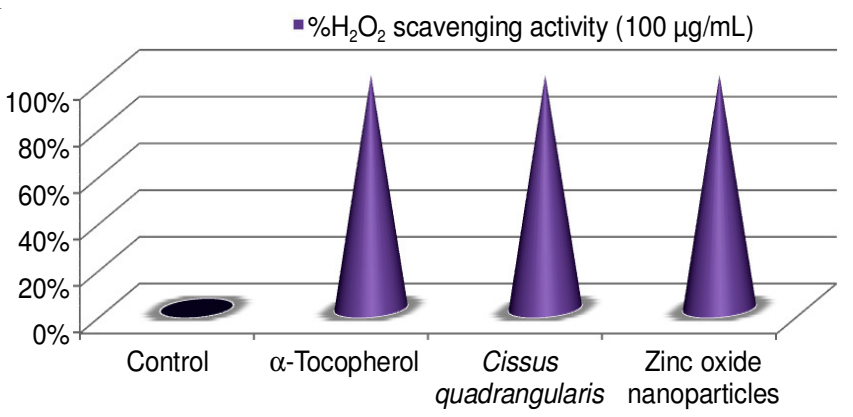

Fig. 5. Antioxidant activity

TABLE-3

ANTIOXIDANT ACTIVITY

\begin{tabular}{lc}
\hline Samples & $\% \mathrm{H}_{2} \mathrm{O}_{2}$ Scavenging activity $(100 \mu \mathrm{g} / \mathrm{mL})$ \\
\hline Control & 0 \\
$\alpha$-Tocopherol & 44.58 \\
Cissus quadrangularis & 22 \\
Zinc oxide nanoparticles & 36 \\
\hline
\end{tabular}




\section{Antiarthritic activity}

Bovine serum protein denaturation method: In in vitro antiarthritic activity by bovine serum protein denaturation method the plant extract $C$. quadrangularis at concentration of $25,50,75,100 \mu \mathrm{g} / \mathrm{mL}$ showed 62,74 and 89 and $90 \%$ inhibition whereas $\mathrm{ZnO}$ nanoparticles showed 74, 82, 90, $93 \%$ inhibition of denaturation of bovin serum whereas, standard diclofenac sodium at $100 \mu \mathrm{g} / \mathrm{mL}$ showed $96.91 \%$ inhibition of denaturation of bovine serum (Table-4).

\begin{tabular}{cccc}
\multicolumn{5}{c}{ TABLE-4 } \\
\multicolumn{4}{c}{$\begin{array}{c}\text { ANTIARTHRITIC ACTIVITY (BOVINE SERUM } \\
\text { PROTEIN DENATURATION METHOD) }\end{array}$} \\
\hline \multirow{2}{*}{ S. No. } & \multirow{2}{*}{ Drug } & $\begin{array}{c}\text { Concentration } \\
(\mu \mathrm{g} / \mathrm{mL})\end{array}$ & Inhibition $(\%)$ \\
\hline 1 & Control & - & - \\
\hline & & 25 & 62 \\
2 & Plant extract & 50 & 74 \\
& & 75 & 89 \\
& & 100 & 90 \\
\hline \multirow{4}{*}{3} & Zinc oxide & 25 & 74 \\
& nanoparticles & 50 & 82 \\
& & 75 & 90 \\
\hline 4 & Diclofenac sodium & 100 & 93 \\
\hline
\end{tabular}

Egg albumin denaturation method: In in vitro antiarthritic activity by egg albumin denaturation method at concentration of $25,50,75,100 \mu \mathrm{g} / \mathrm{mL}$ of aqueous extract of C. quadrangularis showed $75.00,80.31,84.15$ and $89.02 \%$ inhibition of Egg Albumin denaturation whereas the $\mathrm{ZnO}$ nanoparticles showed 77.08, 82.11, 87.11, $91.08 \%$ inhibition of egg albumin denaturation and the standard diclofenac at $100 \mu \mathrm{g} / \mathrm{mL}$ showed $95.77 \%$ inhibition of egg albumin denaturation (Table-5).

\begin{tabular}{cccc}
\multicolumn{5}{c}{ TABLE-5 } \\
& \multicolumn{4}{c}{ ANTIARTHRITIC ACTIVITY } \\
& (EGG ALBUMIN DENATURATION METHOD) \\
\hline \multirow{2}{*}{ S. No. } & \multirow{2}{*}{ Drug } & $\begin{array}{c}\text { Concentration } \\
(\mu \mathrm{g} / \mathrm{mL})\end{array}$ & $\begin{array}{c}\text { Inhibition } \\
(\%)\end{array}$ \\
\hline 1 & Control & - & - \\
\hline & & 25 & 75.00 \\
2 & Plant extract & 50 & 80.31 \\
& & 75 & 84.15 \\
& & 100 & 89.02 \\
\hline \multirow{2}{*}{3} & Zinc oxide & 25 & 77.08 \\
& nanoparticles & 50 & 82.11 \\
& & 75 & 87.77 \\
\hline 4 & Diclofenac sodium & 100 & 91.08 \\
\hline
\end{tabular}

\section{Conclusion}

The results obtained from this study will be facilitating a pathway to extend the performance of $\mathrm{ZnO}$ nanoparticles in biomedical applications to produce suitable drugs, so that it will be beneficial for animals and human beings to abstain from bacterial infections, intestinal worms, rheumatoid arthritis etc. The present method is simple, green, environment-friendly, economical, nontoxic and free of the use of any organic solvents, surfactants and specialized instruments. The phytochemical screening of plant extracts confirms the presence of secondary metabolites such as carbohydrates, tannins, steroids, protein, alkaloids, phenol etc. It shows that some present in high quantity and some are in less quantity. The biomedical applications like antibacterial, antiarthritic, antioxidant and anthelminthic activities were done and concluded the remarkable efficacy of plant extract and synthesized nanoparticles. The plant contains the most of the pharmacological properties such as anticancer, antioesteoporosis, anthelminthic, anti-inflammatory, antioxidant properties as reported in literatures. The comparable study of pharmacological properties of plant extract and synthesized nanoparticles has deduced that the $\mathrm{ZnO}$ nanoparticles contain some of the properties better than the plant extract and can be used in biomedical applications.

\section{REFERENCES}

1. S. Ponarulselvam, C. Panneerselvam, K. Murugan, N. Aarthi, K. Kalimuthu and S. Thangamani, Asian Pac. J. Trop. Biomed., 2, 574 (2012); https://doi.org/10.1016/S2221-1691(12)60100-2.

2. A. Mubayi, S. Chatterji, P. K. Rai and G. Watal, Adv. Mater. Lett., 3, 519 (2012); https://doi.org/10.5185/amlett.2012.icnano.353.

3. K. Lingaraju, H.R. Naika, K. Manjunath, H. Nagabhushana, R.B. Basavaraj, G. Nagaraju and D. Suresh, Appl. Nano Sci., 6, 703 (2016); https://doi.org/10.1007/s13204-015-0487-6.

4. P. Vanathi, P. Rajiv, S. Narendhran, S. Rajeshwari, P.K.S.M. Rahman and R. Venckatesh, Mater. Lett., 134, 13 (2014); https://doi.org/10.1016/j.matlet.2014.07.029.

5. H.J. Zhai, W.H. Wu, F. Lu, H.S. Wang and C. Wang, Mater. Chem. Phys., 112, 1024 (2008);

https://doi.org/10.1016/j.matchemphys.2008.07.020.

6. A.M. Awwad, B. Albiss and A.L. Ahmad, Adv. Mater. Lett., 5, 520 (2014); https://doi.org/10.5185/amlett.2014.5575.

7. T.Y. Suman, S.R. Radhika Rajasree and R. Kirubagaran, Ecotoxicol. Environ. Saf., 113, 23 (2015); https://doi.org/10.1016/j.ecoenv.2014.11.015.

8. R.K. Shah, F. Boruah and N. Parween, Int. J. Curr. Microbiol. Appl. Sci., 4, 444 (2015).

9. R. Dobrucka and J. D³ugaszewska, Saudi J. Biol. Sci., 23, 517 (2016); https://doi.org/10.1016/j.sjbs.2015.05.016.

10. M. Ramesh, M. Anbuvannan and G. Viruthagiri, Spectrochim. Acta A Mol. Biomol. Spectrosc., 136, 864 (2015); https://doi.org/10.1016/j.saa.2014.09.105.

11. M. Manokari and S. Mahipal, World Sci. News, 29, 135 (2016).

12. B.N. Patil and T.C. Taranath, Int. J. Mycobacteriol., 5, 197 (2016); https://doi.org/10.1016/j.ijmyco.2016.03.004.

13. M. Vanaja, G. Gnanajobitha, K. Paulkumar, S. Rajeshkumar, C. Malarkodi and G. Annadurai, J. Nanostruc. Chem., 3, 17 (2013); https://doi.org/10.1186/2193-8865-3-17.

14. R.S. Ruskin, Int. J. Pharm. Sci. Rev. Res., 28, 12 (2014).

15. G. Elango and S.M. Roopan, J. Photochem. Photobiol. B, 155, 34 (2016); https://doi.org/10.1016/j.jphotobiol.2015.12.010.

16. S. Priya and S. Santhi, World J. Pharmacy Pharm. Sci., 4, 2105 (2015).

17. R.J. Ruch, S.J. Cheng and J.E. Klaunig, Carcinogenesis, 10, 1003 (1989); https://doi.org/10.1093/carcin/10.6.1003.

18. S. Keser, S. Celik, S. Turkoglu, O. Yilmaz and I. Turkoglu, Chem. J., 2, 9 (2012).

19. S. Gupta and S. Yadav, Bioremed. Biodeg., 5, 6 (2014); https://doi.org/10.4172/2155-6199.1000250. 